\title{
SLEEP DEPRIVATION-INDUCED HYPERALGESIA IN RODENTS: SOME NEUROCHEMICAL MECHANISMS
}

\begin{abstract}
Received 24.08.13
We assessed the effect of sleep deprivation on the pain thresholds in the thermal and chemical nociceptive tests. Adult male Wistar rats and mice were randomly assigned to the three groups, with no sleep deprivation (control), subjected to 24-h-long sleep deprivation, and sleep-deprived and treated with either an H2 (histamine) receptor antagonist, cimetidine, or a cholinergic receptor blocker, atropine, before deprivation. Sleep deprivation led to significant decreases in both hot plate and tail withdrawal latencies in the thermal tests, a significant increase in the number of writhings in the acetic acid-induced writhing test, and significant prolongation of the licking time in the formalin test $(P<0.05$ in all cases). All changes in the thermal and chemical tests denote noticeable hyperalgesia. Prior administration of both cimetidine and atropine significantly reversed these hyperalgesic changes caused by sleep deprivation as revealed by increases in the thermal latencies in both tests used. We, therefore, conclude that both histaminergic and cholinergic systems play significant roles in sleep deprivation-induced hyperalgesia.
\end{abstract}

Keywords: sleep deprivation, thermal tests, writhing test, formalin test, pain thresholds, histamineergic and cholinergic systems.

\section{INTRODUCTION}

The interaction between such phenomena as sleep and pain has been studied for many years. Although it is well documented that subjects with different pain syndromes suffer from sleep disturbances $[1,2]$, the direction of effects in this relationship is still a matter of debate; the effects observed may not be unidirectional. A few studies in humans support the notion that sleep deprivation produces hyperalgesia [3]. The pioneering study of the effect of sleep deprivation on pain perception was performed by Cooperman et al. [4]. Although the finding of the hyperalgesic effect of sleep deprivation was recently replicated by Onen et al. [5], some other authors failed to demonstrate any effect of total sleep deprivation on nociception and pain [6,7]. Most of studies on the relationship between sleep deprivation and pain perception were descriptive and were not focused on the mechanisms of action. First hints on the mechanism of action responsible for the hyperalgesic effect of sleep deprivation were provided by Ukponmwan et al. [8]. The

\footnotetext{
${ }^{1}$ Department of Physiology, College of Medicine, University of Ibadan, Ibadan, Nigeria.

Correspondence should be addressed to G. F. Ibironke

(e-mail: gibironk@yahoo.com).
}

significance of opioidergic and serotonergic processes in mediating mechanisms of the hyperalgesic changes produced by sleep deprivation were discussed [9].

We tried to further investigate the relationship between sleep deprivation and pain perception in view of the controversial reports, as well as to identify some neurochemical mechanisms underlying the hyperalgesic effect.

\section{METHODS}

Animals. Male albino rats (180-220 g) and mice (50-80 g) were used in the study. They were housed and bred under standard vivarium conditions (room temperature and a 12/12 h light/dark cycle). The animals were fed with standardized mouse cubes and provided with water ad libitum.

Sleep Deprivation. A sleep deprivation technique adapted for rodents was used. This is based on the fact that a decrease in the muscle tone during sleep results in a touch to water and waking. This method results in a complete abolition of paradoxical sleep and a $37 \%$ decrease in slow-wave sleep [10]. In all respective tests, cimetidine and atropine were administered 60 min before sleep deprivation. 
Hot Plate Test. A mild modification of the standard hot plate technique was used $[11,12]$. Rats of the control and sleep-deprived groups were placed on a hot $\left(55 \pm 2^{\circ} \mathrm{C}\right)$ plate set, and the time taken to start licking the paws or jump off from the plate was measured as the hot plate latency. A $60 \mathrm{sec}$ cut-off time was imposed to avoid excessive tissue damage.

Tail Withdrawal Test [13]. Each animal was gently held with a hand towel, and the terminal $3 \mathrm{~cm}$ of the tail was immersed in a water bath $\left(50^{\circ} \pm 1^{\circ} \mathrm{C}\right)$. The time taken by animals to flick their tails out of water (tail-flick latency) was measured.

Formalin Paw Licking Test [14]. Experimental rats were injected with $20 \mu \mathrm{l}$ of $1 \%$ formalin into the dorsal surface of the left hind paw. The duration of licking the injected paws (licking time) observed within the first 5 min post-injection (early phase) and for $10 \mathrm{~min}$ starting at the 20th min post-injection (late phase) were measured.

Acetic Acid-Induced Writhing Test [15, 16]. Experimental mice were i.p. injected with $0.2 \mathrm{ml}$ of $3 \%$ acetic acid to induce the characteristic writhing. The number of writhings (evoked by visceral pain) observed within a 5 to $10 \mathrm{~min}$ post-injection interval was calculated.

\section{RESULTS}

Nociception Tests. Control rats $(n=6)$ took about 5 $\sec (5.17 \pm 0.17 \mathrm{sec}$, on average $)$ to initiate licking the paws or to attempt to jump off from the hot plate in the respective thermal nociception test. At the same time, sleep-deprived rats $(n=6)$ manifested such motor reactions with appreciably shorter latencies (mean, $1.84 \pm 0.41 \mathrm{sec} ; P<0.05$ ) (Fig. 1A).

In another thermal test (tail flick), control rats in most cases withdrew their tail from hot water with a $4-5.5 \mathrm{sec}$ delay $(4.68 \pm 0.51 \mathrm{sec}$, on average). The rats of the experimental group realized this motor response in $3.00 \pm 0.39 \mathrm{sec}$, on average (i.e., the respective latency was only $64 \%$ of that in the control; $P<0.05$ ) (B).

In the formalin test, the total time of paw licking in the control group $(n=6)$ within the first 5-min-long post-injection interval was $56 \pm 1.1 \mathrm{sec}$, while in sleepdeprived rats $(n=6)$ the respective value was $88 \pm$ $\pm 11.3 \mathrm{sec}$, i.e. $57 \%$ greater. Thus, sleep deprivation leads to intensification of acute pain in the mentioned test (Fig. 2B, 1). Within the subsequent time interval, from the 20 th until the 31 st min post-injection,

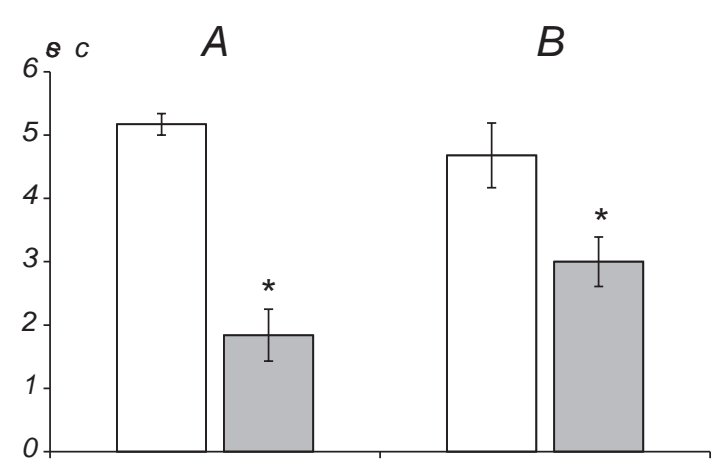

F i g. 1. Diagrams of the latencies (sec) of motor defensive reactions in the hot plate (A) and tail flick (B) tests. Open and dashed columns show the mean \pm s.e.m. values of the latencies in the control and sleep-deprived groups, respectively. ${ }^{*} P<0.05$ compared with the control group.

P и с. 1. Діаграми латентних періодів (c) моторних захисних реакцій в тестах гарячої пластинки $(A)$ та відсмикування хвоста $(B)$.

episodes of licking the impaired limb lasted $38.8 \pm$ $\pm 2.1 \mathrm{sec}$, on average. In sleep-deprived animals, the analogous episodes were more than two times longer $(80.5 \pm 9.0 \mathrm{sec}$, on average; $P<0.05)$ (Fig. 2B, 2). In other words, sleep deprivation enhanced "late" (inflammatory) pain in the formalin test similarly to "early" acute pain, and the increment was noticeably greater than that in the latter case (B).

A parallel, to a significant extent, situation was observed in the acetic acid-induced writhing test on mice. Under conditions of our experiments (see Methods), i.p. injections of acetic acid into control mice $(n=60)$ evoked, on average, $54.2 \pm 1.1$ writhing movements within the observation period. At the same time, the respective value in sleep-deprived mice was $71.8 \pm 2.9$, i.e., about $33 \%$ greater (Fig. 2 A).

Effects of Injections of Cimetidine and Atropine were tested on separate groups of rats in the hot plate and tail flick tests ( $n=6$ in all cases). Sleep deprivation led to the development of noticeable hyperalgesia under conditions of both thermal nociception tests. The relative intensities of hyperalgesic shifts in these groups differed somewhat from those observed in the experiments described above, but the respective values were quite comparable.

Injections of cimetidine completely removed sleep deprivation-induced hyperalgesia in the tail-flick test (Fig. 3B). In another thermal test, the hot plate one, injections of this agent not only smoothed out the shift in the sensitivity to noxious thermal stimulation but even provided a significant analgesic effect. The 
$A$

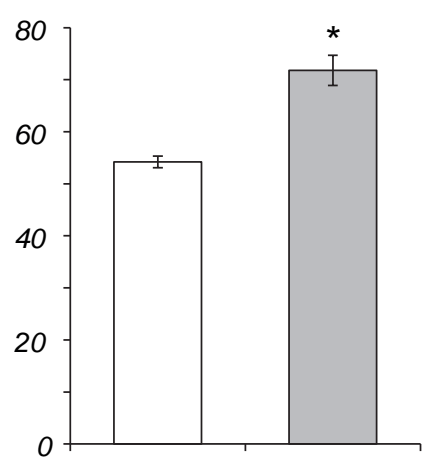

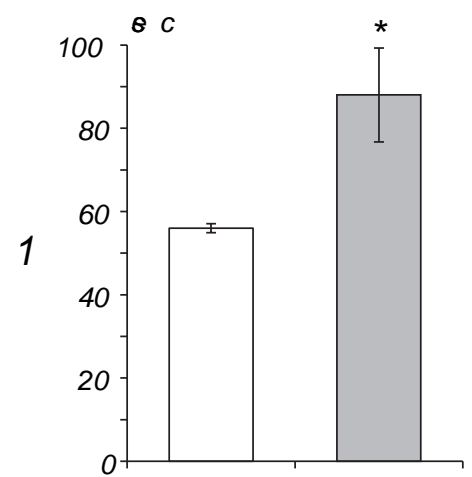

$B$

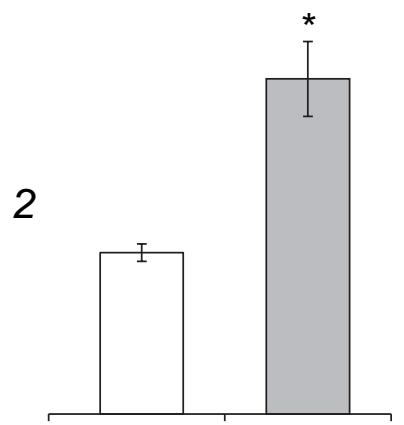

F i g. 2. Diagrams of the numbers of writhings observed in the respective test (A) and durations (sec) of the paw licking in the formalin test within the early (1) and late (2) pain phases. Other designations are the same as in Fig. 1.

Р и с. 2. Діаграми кількості «корчів» у відповідному тесті $(A)$ та тривалості (c) лизання кінцівки у формаліновому тесті $(B)$ у межах ранньої (1) та пізньої (2) фаз розвитку болю.

latency of defensive motor activity was in this case more than four times longer than that in the control group and 13 times longer than in the sleep-deprived nontreated group (A).

Injections of atropine exerted effects parallel, in some aspects, to those induced by cimetidine injections. The mean latencies of responses in the hot plate and tail withdrawal tests after introduction of atropine were not only significantly longer than in sleep-deprived animals with no atropine treatment
A

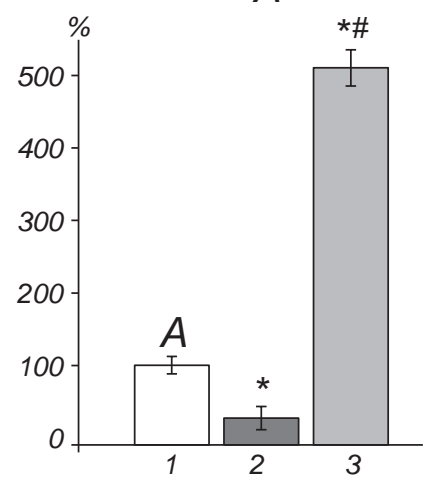

$B$

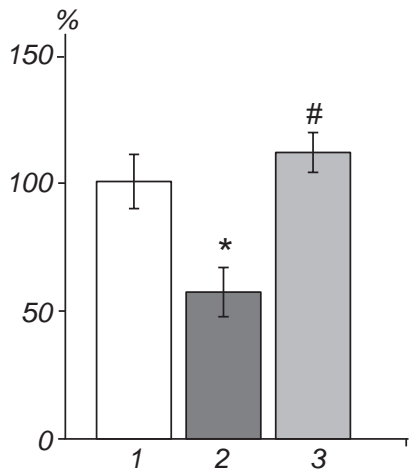

F i g. 3. Effects of cimetidine on the hot plate $(A)$ and tail flick $(B)$ normalized latencies (\%) in the control (1), sleep-deprived (2), and sleep-deprived+treated groups (3). Latencies in the control group are taken as $100 \%$. ${ }^{*} P<0.05$ compared with the control; $\# P<0.05$ compared with the sleep-deprived group.

Р и с. 3. Впливи ціметидіну на нормовані значення (\%) латентних періодів у тестах гарячої пластинки $(A)$ та відсмикування хвоста (B) у контрольних (1), підданих позбавленню сну (2) та позбавлених сну з попереднім уведенням ціметидіну (3) тварин. but even somewhat longer (by 21 and 36\%) than the respective values in control intact rats (Fig, 4A, B).

\section{DISCUSSION}

We observed clear hyperalgesic effects of sleep deprivation in experiments on rats and mice. These changes in nociception are in accordance with previous studies on humans $[4,5]$ in which sleep deprivation was found to decrease the pain thresholds. Furthermore,

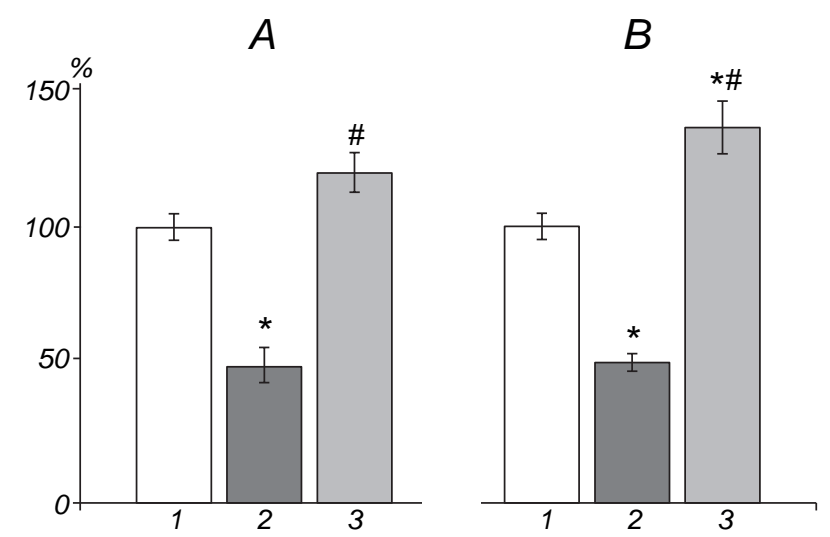

F i g. 4. Effects of atropine on the hot plate $(A)$ and tail flick $(B)$ normalized latencies (\%) in the control (1), sleep-deprived (2), and sleep-deprived+treated groups (3). Other designations are the same as in Fig. 3.

Р и с. 4. Впливи атропіну на нормовані значення (\%)латентних періодів у тестах гарячої пластинки $(A)$ та відсмикування хвоста $(B)$. 
the results of several animal studies also supported the view that sleep deprivation enhances nociception $[17$, 18]. Our above-described findings contradict a few previous reports that failed to identify any effect of sleep deprivation on the pain thresholds $[6,7]$. This discrepancy is probably caused by some differences in the study design, especially in the conditions of sleep deprivation. We tested the effects of 24-h-long continuous sleep deprivation in rodents, while the authors of the contradictory findings investigated the effects of two nights of sleep deprivation separated by a 24-h-long recovery sleep in humans. The possibility of some other existing factors also cannot be ruled out.

The underlying mechanisms by which sleep deprivation decreases pain thresholds remain mostly unclear. As was found $[8,9]$, the analgesic action of endogenous and exogenous opioids is dependent on undisturbed sleep architecture/continuity. Furthermore, sleep deprivation was shown to affect the serotoninergic system, which plays an important role in the pain inhibitory control [18]. These findings suggest that sleep deprivation produces a transient disturbance of descending influences coming from the cerebral pain inhibitory control systems. Our findings showed that prior administrations of either histaminergic or cholinergic receptor blockers before sleep deprivation practically completely smooth out deprivationinduced hyperalgesic shifts and can even exert some analgesic effects. Thus, the significant roles of the histaminergic and cholinergic systems in the development of sleep deprivation-induced hyperalgesia should be taken into account. At the same time, it is obvious that neurochemical mechanisms of such hyperalgesia need further investigations.

The above-discribed experiments were carried out in agreement with the internationally accepted ethical norms for the works on vertebrate animals.

The authors, G. F. Ibironke and C. O. Ajonijebu, confirm that they have no conflict of interest.

\section{Г. Ф. Ібіронке ${ }^{1}$, К. О. Айоніджебу ${ }^{1}$}

ДЕЯКІ НЕЙРОХІМІЧНІ МЕХАНІЗМИ ГІПЕРАЛГЕЗІЇ, ВИКЛИКАНОЇ ПОЗБАВЛЕННЯМ СНУ, У ГРИЗУНІВ

\footnotetext{
${ }^{1}$ Ібаданський Університет (Нігерія).
}

P е 3 ю м е

Ми оцінювали впливи позбавлення сну на пороги болю, що визначалися в термальних та хімічних ноцицептивних тестах. Дорослі самці щурів лінії Вістар та мишей були рандомізовано розподілені на три групи: тварини без депривації (контроль), піддані позбавленню сну протягом 24 год, а також піддані позбавленню сну з попереднім уведенням або антагоніста гістамінових Н2-рецепторів ціметидіну, або блокатора холінергічних рецепторів атропіну. Позбавлення сну призводило до вірогідних зменшень латентних періодів моторних реакцій у тестах гарячої пластинки та відсмикування хвоста, істотного збільшення кількості «корчів»у відповідному тесті з внутрішньоочеревинним уведенням оцтової кислоти та до вірогідного збільшення тривалості лизання кінцівки у формаліновому тесті $(P<0.05$ у всіх випадках). Зміни індексів у всіх термальних та хімічних тестах свідчили про розвиток помітної гіпералгезії. Попередні введення ціметидину та атропіну значною мірою усували ці прояви гіпералгезії, викликані позбавленням сну, на що вказувало збільшення латентних періодів захисних реакцій в обох використаних термальних тестах. Отже, і гістамінергічна, і холінергічна системи відіграють істотну роль у гіпералгезії, викликаній позбавленням сну.

\section{REFERENCES}

1. P. Jennum, A. M. Drewes, A. Andreasen, and K. D. Nielsen, "Sleep and other symptoms in primary fibromyalgia and in healthy controls," J. Rheumatol., 20, 1756-1759 (1993).

2. C. M. Morin, D. Gibson, and J. Wade, "Self-reported sleep and mood disturbances in chronic pain patients," Clin. J. Pain, 14, 311-314 (1998).

3. B. Kundermann, J. C. Krieg, W. Schreiber, and S. Lautenbacher, "The effect of sleep deprivation on pain," Pain Res. Manag., 9, 25-30 (2004).

4. N. R. Cooperman, F. J. Mullin, and N. Kleitman, "Studies on the physiology of sleep: Further observations on the effects of prolonged sleeplessness," Am. J. Physiol., 107, 589-594 (1934).

5. S. H. Onen, A. Alloui, A. Gross, et al., "The effect of total sleep deprivation, selective interruption and sleep recovery on pain tolerance thresholds in healthy subjects," J. Sleep Res., 10, 35-42 (2001).

6. S. A. Older, D. F. Battafarano, C. L. Danning, et al., "The effects of delta wave sleep interruption on pain thresholds and fibromyalgia-like symptoms in healthy subjects; correlation with insulin-like growth factor 1," J. Rheumatol., 25, 11801186 (1998).

7. T. Arima, P. Svensson, C. Rasmussen, et al., "The relationship between selective sleep deprivation, nocturnal jaw-muscle activity and pain in healthy men," J. Oral Rehabil., 28, 140148 (2001).

8. O. E. Ukponmwan, J. Rupreht, and M. R. Dzoljic, "REM sleep deprivation decreased the antinociceptive property of enkephalinase - inhibition, morphin and cold-water-swim," Gen. Pharmacol., 15, 255-258 (1984).

9. B. Kundermann, J. C. Krieg, W. Schreiber, and 
S. Lautenbarcher, "The effect of sleep deprivation on pain," Sleep Med., 10, 356-369 (2006).

10. R. B. Machado, D. C. Hipolide, A. A. Benedicto-Silva, and F. Tufik, "Sleep deprivation induced by modified platform technique: quantification of sleep loss and recovery," Brain Res., 1004, 45-51 (2004).

11. N. B. Eddy and D. Leimbach, "Synthetic analgesics II: Dithienylbutenyl- and dithienylbutylamines," J. Pharmacol. Exp. Ther., 98, 121-137 (1953).

12. G. F. Ibironke, O. J. Saba, and F. O. Olopade, "Glycemic control and pain threshold in alloxan diabetic rats," Afr. J. Biomed. Res., 7, 147-151 (2004).

13. F. E. D'Amour and D. L. Smith, "A method for determining loss of pain sensation," J. Pharmacol. Exp. Ther., 72, 149-151 (1941).
14. S. Hunskaar and K. Hole, "The formalin test in mice: dissociation between inflammatory and non-inflammatory pain," Pain, 30, 103-114 (1997).

15. E. Siegmund, R. Cadmus, and G. A. Lu, "A method for evaluating non-narcotic and narcotic analgesics," Proc. Soc. Exp. Biol. Med., 9, 729-731 (1957).

16. R. Koster, M. Anderson, and E. J. De Beer, "Acetic acid for analgesic screening," Fed. Proc., 18, $412-413$ (1989).

17. R. A. Hicks, J. D. Moore, P. Findley, et al., "REM sleep deprivation and pain thresholds in rats," Percept. Mot. Skills, 4, 848-850 (1978).

18. C. A. Blanco-Centurion and R. J. Salin-Pascual, "Extracellular serotonin levels in the medullary reticular formation during normal sleep and after REM sleep deprivation," Brain Res., 923, 128-136 (2001). 